\title{
Lexical and Grammatical Means of Expressing Modality in the German Language as one of the Aspects of Teaching a Foreign Language while Training Post-Graduate Students ${ }^{1}$ PONOMARYOVA Liliya, ${ }^{2^{*}}$ OSADCHA Elena
}

${ }^{1}$ Oles Honchar Dnipropetrovsk National University, Ukraine

${ }^{2}$ Oles Honchar Dnipropetrovsk National University, Ukraine ${ }^{2}$

1Email address: lilienp@gmail.com

$2^{*}$ Email address: elena.osadcha@gmail.com

\begin{abstract}
Keywords: modality, aspects of modal attitude, means of expressing modality, ways of translating, post-graduate students
\end{abstract}

\begin{abstract}
The aim of the article is to analyze lexical and grammatical means of expressing modality in the literature on technical sciences in German and the ways of their translating. Basing on the aim of the research, it is necessary to solve the following problems: 1) to distinguish the means of expressing modality in the literature on technical sciences; 2) to define the role of lexical and grammatical means of expressing modality in a special test; 3) to identify the means of expressing modality which are the most difficult to translate and to understand in the test; 4) to give some recommendations as to developing and improving the skills of translating and using the means of expressing modality in speech.
\end{abstract}

\section{INTRODUCTION}

The selection of the teaching language material is of great importance for all kinds of educational establishments at all levels of education. The language material selection for teaching post-graduate students sets two main goals: to learn how to read the literature on technical sciences and to acquire the speaking and listening skills within the communication on the professional issues.

Knowing lexical and grammatical means of expressing the attitude to what is being said enables the speaker while reading the text on technical sciences to understand the author's point of view, because all the aspects of the modal attitude, both external and internal, are reflected in the text. More extensive studying of modality meets the aims and tasks of communicatively oriented teaching foreign languages.

As it is known, all lexical and grammatical patterns are usually introduced in the texts and situations that are relevant to the aims of the academic process. Post-graduate students are involved in working with a lot of the scientific material written in a foreign language. It is usually connected with the area of their research.

The material studied at the post-graduate department contains the topics that are already known to students but necessary to extend and study at a deeper level and those that are relatively new or requiring some training. Studying the means of expressing modality in the German language is limited mainly to studying modal verbs both in the school and university programmes. They belong to the key themes of the revision course for the post-graduate department and are included in the unit "Passive" which is thoroughly studied during both the revision course and the main course, taking into consideration its importance while reading and translating scientific technical literature. Besides the modal verbs, the means of translating constructions haben, sein $+z u+$ Infinitiv are considered. Other means of expressing modality such as modal words and word combinations as well as modal verbs with Infinitiv I и II for expressing different degrees of probability and Futurum II don't get sufficient attention not only while teaching reading and translating scientific technical literature but also understanding oral speech. They are generally not distinguished into a separate group but studied while considering other themes. 


\section{SEMANTIC, MORPHOLOGICAL AND GRAMMATICAL CHARACTERISTICS OF EXPRESSING MODALITY}

In linguistics there are many scientific works devoted to the semantic, morphological and syntactical peculiarities of the means of modality (V. Admoni, N. Arutyunova, S. Bally, E. Belyayeva, A. Bondarko, L. Zinder, L. Stroyeva, E. Shendels, J. Buscha, U. Engel, J. Erben, G. Helbig, W. Jung, F.R. Palmer, A. Weidner, H. Weinrich and others). The multisided semantics and the means of its expressing, a wide variety of the relations between the form and the contents in the process of the language functioning are the characteristics of modality. V. Vinogradov considered modality as the main language category which is characteristic for different languages and has specific forms of expression depending on the system of a definite language [1: 57].

Despite some differences in the assessment of the essence and limits of modality, some researchers believe that modality characterizes a sentence as a whole $[2: 8 ; 3: 448 ; 4: 49]$. This allows considering modality as a semantic category which is a quality of the whole content of a statement. So, within a sentence modal words perform a direct lexical function and are necessary for correct and complete understanding of both written and oral statement. Taking V.Vinogradov's understanding of the essence of modality as a basis, many scientists distinguish three aspects of modality. They are the internal modality, the attitude of a speaker to the action he is doing and the external modality which may be objective and express the relations between the contents of a statement and the reality or unreality and subjective modality which may express the speaker's degree of certainty of the facts reported or his attitude to the statement in general.

While using modal verbs, modal words and word combinations, we express our attitude to the action performed, react to the current situation or predetermine it. Doing this, the speaker influenced by his own personal perception either distorts modality which is characteristic for a foreign language, or brings in the modality which is characteristic for his native language into the statement. This can result in misunderstanding and both kinds of distortion, as a rule, are found simultaneously. The reason of it is dubbing the main modal meanings within a language, as well as inequality of the quantity of modal meanings in different languages. Thus, for example, there are two equivalents of the Russian verb "must" in the German language (müssen and sollen) and there are at least three of them in the English language (must, should and ought to).

\section{THE MEANS OF EXPRESSING MODALITY AND THE WAYS OF TRANSLATING THEM}

There is a whole variety of the ways of expressing modal meaning depending on the scientific school a scientist belongs to. As modality is an extra-linguistic category which expresses the attitude of a speaker to the reality, it may have some common means of its expressing in different languages, which include:

- phonetic means (stress, intonation);

- lexico-grammatical means (modal words) which express subjective modality;

- grammatical means which express grammatical modality [3;308].

In the scientific technical literature all the above mentioned aspects of the modal relations can be found. Modal verbs, modal words and word combinations express all the types of the author's attitude to the facts reported [5]. J. Rezker considers that in theory and practice of the translation, the task is to convey the subjective modality not only with the help of phonetic but also with help of lexico-grammatical, lexical and grammatical means [6:170].

As far as translating scientific technical literature is concerned, V. Karaban considers that it is translated with the help of the lexico-grammatical means of expressing modality [7;49].

In this respect it seems to be worthwhile using semantic classification which includes two classes of modal words and word combinations in the process of studying the ways of expressing modality [7:214]:

1. Modal words and word combinations, expressing certainty of what is said: zweifellos, zweifelsohne, ohne Zweifel, kein Zweifel, schlechterdings, natürlich, selbstverständlich, unbedingt, 
bestimmt, durchaus, klar, wohlverstanden, verständlicherweise, selbstredend, versteht sich, allerdings, freilich, zwar, wahrhaftig, wahrhaft, wahrlich, wirklich, fraglos, in Wirklichkeit, tatsächlich, in der Tat, sicher, mit Sicherheit, sicherlich, gewiss, gewisslich, fürwahr.

2. Modal words and word combinations expressing supposition, doubt in what is reported: offenbar, anscheinend, scheinbar, offensichtlich, sichtlich, augenscheinlich, voraussichtlich, vielleicht, wohl, wahrscheinlich, hoffentlich, womöglich, möglicherweise, vermutlich, eventuell, etwa, kaum, angeblich, schwerlich.

These means of expressing the attitude to what is said allows better understanding the author's point of view while reading scientific technical text. It is necessary to underline that while translating texts, students often omit or don't translate the words of the given categories without paying any attention to them which makes the quality of the translation lower. That's why it seems worthwhile paying more attention to this problem while planning the academic process and designing a whole range of exercises both for translation and for developing speaking skills.

The words of the first category are used to emphasize the correctness of a statement, show that a decision is categorical, certainty of existing the facts and phenomena reported:

Gewiss, darf man nicht annehmen, dass ....- Undoubtedly, it is impossible to consider that ...

The words of the second class are used in the case when a speaker is not aware enough of a certain fact or phenomenon. He can not affirm or deny categorically that the contents of a statement correspond to reality that's why he makes his statement with a certain degree of probability depending on the degree of his own awareness, either he doubts or is not certain of the facts reported:

Es ist kaum möglich, dass .... - It is hardly possible ....

If the omission of the modal words of the first class doesn't considerably affect the affirmative contents of a statement, the omission of the modal words of the second class makes noticeable changes into the modal characteristic of a statement because it loses its suppositional modality and acquires the character of affirmative modality.

Given modal words and word combinations can be found especially often in the parts of scientific articles which contain discussion (Diskussion) - discussing the material presenting the results and forecasts of the research. The knowledge of these words allows correct understanding of the essence of the presented material and the problems connected with the presented content, certainty or probability of the existence of facts and phenomena.

Using some words for expressing the attitude to what is stated it is necessary to distinguish them from the other meanings of these words. For example, using the word for expressing probability etwa which means quite, probably in the sentence Das ist etwa nur in den Fällen möglich, in denen ...

- It is quite possible only in the cases when ..., should be distinguished from the other meaning of he word nearly, approximately in the sentence Die Temperatur von etwa $300^{\circ} \mathrm{C}$. - The temperature is approximately $300^{\circ} \mathrm{C}$. In this case the numeral usually follows the word etwa.

The word gewiss besides its modal meaning of certainty has also the concessional meaning, for example:

Gewiss, darf man nicht annehmen, dass .... - No doubt, it's impossible to think that, ....

Gewiss ... aber ... -It' true..., however, ...

It is not uncommon for the words of the German sentence in the process of translating them into other languages appear redundant and be omitted, as for example, in word combination of the verb scheinen (seem) and modal word wohl (rather) which are used for expressing supposition. One of them should be omitted.

Diese Auffassung scheint wohl schon. - This point of view, as far as we can judge, has (rather is omitted) been refuted. 


\section{THE WAYS OF IMPROVING AND DEVELOPING POST-GRADUATE STUDENTS' SKILLS OF TRANSLATING AND USING THE MEANS OF MODALITY}

According to the communicative principle of teaching foreign languages, the practical aim of it is to form the habits and skills necessary for successful communication. Post-graduate students are supposed to work extensively with numerous sources of scientific information written in foreign languages. This will enable them to keep up-to-date with the latest advances in the field if their investigation and make scientific conclusions at a deeper level. Besides, they will not be isolated from the rest of the scientific community in the world.

Language learning usually goes on in an integrative way, so lexical, phonetic and grammatical phenomena are studied simultaneously and are introduced in one text. Grammatical skills should be automatic, flexible, stable and gradually formed. They are divided into reproductive (the ones that can be reproduced in oral and written speech) and perceptive (the ones that can be recognized in the oral and written text during reading and listening comprehension). Both of these groups are equally important for the professional training of the post-graduate students. On the one hand, they will make their own reports and presentations and take part in discussions. On the other hand, they will read a lot of scientific articles and listen to their colleagues' reports.

For better understanding the statements with the modal meaning, it is possible to suggest doing the following groups of exercises:

1. Express supposition, doubt, certainty, uncertainty of what is reported in the given statement or in a short text;

2. Replace modal verbs with modal words or modal word combinations with the same semantics without changing the meaning of the statement.

Modal verbs with the infinitive are known to perform two functions. Retaining their lexical meaning, they can express the attitude of a speaker to the action as possible, necessary, obligatory and desirable. While changing its lexical meaning, they express supposition with a different degree of probability. Besides traditional modal verbs können, dürfen, müssen, sollen, wollen, mögen, the verbs brauchen vermögen, wissen, verstehen [8:416], scheinen, pflegen, wissen, suchen, haben, sein can also be referred to the verbs that have modal meaning. U. Engel suggests dividing German verbs into two groups: modal verbs and semi-modal verbs [3]. The above mentioned traditional verbs and the verbs brauchen $u$ werden are referred to this group. The verbs pflegen, scheinen, haben, sein, stehen, umhin können, vermögen, verstehen, wissen are referred to the second group. The verbs können and mögen with Infinitiv I express a careful subjective supposition, while using können in Imperfekt Konjnktiv this shade of meaning is more expressed.

In diesem Fall kann (könnte) auch ein Einfluss der magnetischen Wellen vorhanden sein. - In this case, probably, there is some influence of the magnetic waves.

While using modal verbs, the main meaning of a modal verb may be partially lost and the verb itself may not be translated at all, but conveyed with the help of modal adverbs possibly, rather, likely, evidently, must be. This desemantization is especially characteristic of the verb dürfen.

Es dürfte sich erübrigen, hier nochmals auf die diesbezüglichen Einzelheiten einzugehen. - It is rather unnecessary to touch upon the details that have something to do with it.

Modal verbs, when used with Infinitiv II, express various shades of supposition and are translated, as a rule, by the intriductory words and constructions: müssen - must be, undoubtedly; können - maybe, quite possible; sollen - judging by (the reports), if considered, evidently, as far as it is known.

Eine genaue spektroskopische Bestimmung von $\mathrm{m} / \mathrm{mh}$ muss zugleich eine genauere Kenntnis von $\mathrm{e} / \mathrm{m}$ bedeutet haben. - The accurate spectrographic analysis $\mathrm{m} / \mathrm{mh}$ is sure to provide the more accurate measuring e/m at the same time.

Das kann noch vor 1900 gewesen sein. - It may have happened before 1900.

Neulich wurde ein kleines Radargerät gebaut. . Das Gerät sollte nicht mehr als 200 Gramm gewogen haben. - The miniature radiolocator has recently been constucted. According to the data available, the device weighs only $200 \mathrm{~g}$. 
Very often this shade of meaning may be emphasized. For example,

Es mag sehr lange gedauert haben, bis die Elektronenröhre, die eine Revolution in der Hochfrequenztechnik hervorgerufen hat, erfunden wurde. - A lot of time may have passed before the electric lamp was created, which resulted in the revolution in the area of high-frequency technology.

Futurum II is used in scientific technical literature to express supposition as for any action which is going to happen in future.

Die Raumfahrt wird ihren Höhenpunkt erreicht haben, wenn .... - Space travel is likely to achieve its climax when...

Dieses Problem wird (wohl) nicht bald gelöst worden sein. - Evidently, this problem will not be solved soon.

A typical mistake while translating the sentences with Futurum II is their translation with the help of the Future tense or Passive voice. While translating the sentences with Futurum II, it's necessary to use introductory words and constructions which express supposition, for example, evidently, rather, as far as we can judge.

To develop the skills of translating the lexico-grammatical phenomena that are characteristic for the German scientific technical literature, it is necessary to create special exercises with practical recommendations where the emphasis is made on the most complicated moments for learning definite material and where the most typical mistakes can be prevented. The texts which contain the maximum amount of the lexico-grammatical material studied that is combined with the synonymic forms should be chosen. It will help to learn the material more effectively.

It's necessary to notice that the category of modality, semantics and functioning of modal verbs, the ways of expressing them and translating lexico-grammatical means of expressing modality are rather substantially studied in the linguistic literature and are reflected in practical courses of translating scientific technical literature [A. Arkhipov, A. Kanshper, R. Synev, F. Hayt].

As we see it, in the course of training post-graduate students it is worthwhile studying a separate topic "Lexico-grammatical means of expressing modality in the German language and the ways of translating them", because it belongs to the language phenomena with wide semantics which are the most difficult for the translation. As modality expresses not only the relationships between the statement and reality, but also the attitude of the speaker to this reality, the more complete learning modality is not the aim in itself, but allows solving the problems of communicatively oriented teaching foreign languages.

\section{CONCLUSIONS}

Foreign language training of post-graduate students is quite important at the present stage of development of modern science. Discoveries here happen so quickly that it is impossible to keep pace without being able to learn about them immediately from scientific journals. Young scientists are supposed to take part in conferences abroad, make their own presentations and reports and take part in discussions. The perceptive and reproductive grammatical and lexical skills are of great importance. Modality and the ways of its expressing is an important aspect of studying a foreign language, because the lack of knowledge of its peculiarities in German and English may lead to misunderstanding and distorting the information which is very undesirable when it comes to sciences. Knowing the ways of expressing modality makes it possible to understand the external and internal attitude of the speaker to the information he presents.

In the scientific linguistic literature there are a lot of works devoted to modality. The authors have different opinions as for the assessment of the essence and limits of modality. Due to the great variety of the means of expressing modality, learners may face some difficulty understanding and translating the sentences with modal verbs, modal words and word combinations.

In this work there has been made an attempt to analyze the difficulties students may have, to identify the most common mistakes and to find the ways how to foresee and avoid them. 


\section{References}

[1] V.Vinogradov, On the category of modality and modal words in the Russian Language, in: V. Vinogradov, Research into Russian Grammar, Moscow, 1975, pp. 53-87.

[2] E.Shendels, Practical Grammar of the German language, Moscow, 1988, 416 pp.

[3] U.Engel, Deutsche Grammatik, Heidelberg, Groos, 1991. - 888 p.

[4] J.Erben, Abriss der deutschen Grammatik, Berlin, Akademie Verl, 1966, 316 pp.

[5] A.Weidner, Die russischen Übersetzungsäqivalente der deutschen Modalverben : Versuch einer logisch-semantischen Charakterisierung, München, Verlag Otto Sagner, 1986, Bd. 203, 336 pp.

[6] J. Rezker, The theory of translation and translating practice, Moscow, 2006, $240 \mathrm{pp}$

[7] V. Karaban, Translation of English scientific and technical literature into Ukrainian, Kyyv, 1997, 299 pp.

[8] O. Moskalskaja, Grammatik der deutschen Gegenwartssprache, Moskau, Vysśaja Śkola, 1983, $344 \mathrm{pp}$. 